\title{
METHOD OF STIMULATION OF PHARMACY WORKERS INVOLVED IN THE GOVERNMENT PROGRAM "AVAILABLE MEDICINES"
}

\author{
Svitlana Moroz \\ Department of Organization and Economics of pharmacy \\ National University of Pharmacy \\ 53 Pushkinska str., Kharkiv, 61002, Ukraine \\ m.sg@ukr.net \\ Alla Nemchenko \\ Department of Organization and Economics of pharmacy \\ National University of Pharmacy \\ 53 Pushkinska str., Kharkiv, 61002, Ukraine \\ Maryna Podgaina \\ Department of Organization and Economics of pharmacy \\ National University of Pharmacy \\ 53 Pushkinska str., Kharkiv, 61002, Ukraine \\ Olena Vynnyk \\ Department of Organization and Economics of pharmacy \\ National University of Pharmacy \\ 53 Pushkinska str., Kharkiv, 61002, Ukraine \\ Diana Zoidze \\ Department of Management and Administration \\ National University of Pharmacy \\ 53 Pushkinska str., Kharkiv, 61002, Ukraine
}

\footnotetext{
Abstract

The aim is to study the current state of the organization of work in pharmacies under the government program "Available medicines" and to create proposals for the improvement of material incentives to increase the motivation of workers of such pharmacies.

Materials and methods. The research used the general methods of scientific knowledge: analysis and synthesis, analogy and comparison; method of questioning to determine the actual state and opinions of specialists on the organization of work in the conditions of pharmacy participation in the program "Available medicines".

Results and discussion. In the course of the study, the problem of lack of incentives and motivation for the work of pharmacy workers under the Government program "Available medicines" has been highlighted. According to the results of the survey of specialists of three different forms of pharmacy' ownership, participating in the program of reimbursement of the cost of drugs, it was found that the volume and intensity of work of workers has significantly increased, and wages have remained at the same level. The number of operations performed by employees in such pharmacies has considerably increased, which is related to the registration and maintenance of recipes under the program "Available medicines". The questionnaire survey has showed that the best option for optimizing the organization of remuneration in the prevailing conditions would be to pay extra for work (overpays). It was found that the number of recipes taken by one pharmacist per day varies considerably in different pharmacies, and there are also differences in the duration of the work of pharmacies under the reimbursement program during the month. To increase the motivation of pharmacists to work in the prevailing conditions, the method of calculating the additional payment for work in the conditions of the program "Available medicines" for each chemist's worker is offered individually in accordance with the post based on a formula that takes into account the intensity of labor using the intensity coefficient and the percentage of the additional payment.

Conclusions. The conducted researches have shown that the increased intensity of labor, which takes place in pharmacies working under the program "Available medicines", is the basis for the calculation of additional payments. The application of the
} 
system of material stimulation of the work of pharmacists based on the proposed methodology will allow compensating additional labor of specialists, taking into account the intensity of their work.

Keywords: salary, pharmacy workers, organization of work in pharmacies, government program "Available medicines", material incentives, overpay (additional payment)..

\section{Introduction}

Nowadays in Ukraine, significant changes have place in the pharmaceutical providing of the population sphere that are appeared in the organization of pharmacists' work because they realize these changes and become immediate executants of this process. As it is known, from April 1, 2017, Ukraine has a government program "Available medicines", in which patients can receive medicines by prescription free or overpay for the treatment of cardiovascular disease, diabetes type II and bronchial asthma. Currently, 6179 pharmacy establishments operate in the program [1]. Of course, the results of this project have positive indicators: the number of emergencies with suspected stroke or heart attack has reduced by $4.2 \%$, nearly $6 \%$ - for people with bronchial asthma attacks [2].

At the same time, the implementation of the program has significantly influenced the work of pharmacies involved in the program "Available medicines". In this regard, a number of problematic aspects have been formed, that complicate the activity of pharmacies and the organization of their work.

The study of the organization of labor and its payment, in particular in the pharmaceutical field, is always relevant and important, since it concerns both individual workers and collectives, institutions as a whole. Some aspects concerning the providing of social guarantees, benefits for certain categories of workers in the pharmaceutical industry are highlighted in studies of Tolochko V. M., Zarichkova M. V., Halii L. V. [3-5], reflected some aspects of motivation and stimulation of labor pharmacists [6, 7]. At the same time, it should be noted that to the problems of the organization and salary payment of pharmacy workers, which are participated in the medicines reimbursement programs, that has increased the intensity of activity of pharmacists in several times, very few attention has been paid. Therefore, this urgent problem requires a study about the financial incentives for pharmacists involved in the drug reimbursement program.

The current problem of organizing the work of pharmacy workers in terms of work on the program of reimbursement of medicines is in several planes. First, the pharmacy is responsible for the dispensing of medicines for a wrongly prescribed or falsified recipe. In this case, the cost of these drugs is not reimbursed to pharmacies [8].

Secondly, the volume of documentation that needs to be issued for the reimbursement of the cost of the drug has significantly increased for pharmacy workers, since all documents under the "Available medicines" program are filled in paper form. In fact, a pharmacist spends about 10 minutes on patient service with one recipe; often there are situations where one person has several recipes [9]. This necessitates the maintenance of additional staff and additional payments.

Thirdly, due to inadequate planning of the amount of necessary funds for the reimbursement by the healthcare establishments, funding is very uneven. Therefore, there are cases where planned monthly funds are being used by pharmacies in the first decade, and sometimes in the first 5 days, of the month. At the same time, the intensity of pharmacist's activity and the complexity of their operations has been increased several times.

The government program does not foresee any (economic or noneconomic) incentives for pharmacies or pharmacists, although the volume of work for pharmacy workers has significantly increased: the recipe needs to be checked out, to draw up and filled in with the required reporting [10].

The experience of other countries, in particular Poland, has shown that one of the biggest problems faced by pharmacists is related to the reimbursement of the cost of drugs. According to the requirements of the National Health Fund of Poland, the recipe must comply with established 
standards and contain a lot of information. Accountability under the recipes is quite strict. A pharmacist registers recipe data personally. Every week, pharmacies send a prescription report to the National Health Fund. If an error has been made in one of the recipes included in the report, the reimbursement will not be made until the error is not correct [11].

Similar reimbursement programs for drugs in other European countries operate in a slightly different way. Pharmacies are not self-sustaining companies, not supermarkets, focused on profit from trade there, pharmacies - the healthcare institutions to which the state pays for patient services 15-19 euros for each patient. Thus, in Ukraine, it is necessary to make the "Available medicines" program more attractive for pharmaceutical establishments [12].

\section{Aim of the research}

The aim of the study is to investigate the current state of the organization of work in pharmacies under the Government program "Available medicines" and to develop proposals for the improvement of material incentives in order to increase the motivation of the workers of the pharmacies.

\section{Materials and methods}

The research used the general methods of scientific knowledge: analysis and synthesis, analogy and comparison, graphical method.

A questionnaire survey was carried out using a specially designed questionnaire to study the opinions of the pharmacy specialists regarding the actual status and organization of work under the conditions of the participation of pharmacies in the "Available medicines" program. Inspected pharmacists of pharmacy establishments of different forms of ownership. The obtained coherence coefficient $(\mathrm{W}=0.8015, \mathrm{p}<0.05)$ indicates a high consistency of respondents' answers, therefore, with a probability of $95 \%$, it can be argued that the consistency of the answers of respondents is not accidental.

\section{Results}

To find out the actual state and current problems in the organization of pharmacist's' activity by in the program "Available medicines" and in order to further develop ways to optimize the work of pharmacists survey was conducted in Kharkiv and Kharkiv region during September 2018. The survey was conducted through a questionnaire to study the opinions of the pharmacists on the individual aspects of the organization of their work. The questionnaire was conducted in the municipal pharmacy of the Communal Enterprise "Lozova Municipal Pharmacy" and private pharmacies of the networks "Dosvid. Dovira. Dopomoga." and "9-1-1 Gamma-55". The survey was attended by 20 pharmacists (5 employees of the Communal Enterprise "Lozova Municipal Pharmacy" and 15 pharmacists of private networks) who, in order to ensure the representativeness of the data, meet the requirements of high qualification, sufficient professional and work experience.

To the question "Has the quantity of visitors increased in the pharmacy?" all respondents answered "Yes". In addition, $100 \%$ of respondents have noted that the complexity of the work has increased, while wages has not increased during the time of the pharmacy's accession to the "Available medicines" program.

It is investigated the quantity of time that pharmacists actually spend on the one prescription according to the program "Available medicines" taking into account all the procedures specified above (Fig. 1).

When analyzing the conditions of work of pharmacists it was found that the number of recipes taken by one pharmacist per day varies greatly in various pharmacies (Table 1). This is due to the amount of funding provided to the health care establishment for a month and, accordingly, to the pharmacy, which made an agreement with it.

During our survey of pharmacists working in the "Available medicines" program, we have asked of how to optimize the organization of work and its payment in modern conditions. The analysis of respondents' answers is presented in Fig. 2. 


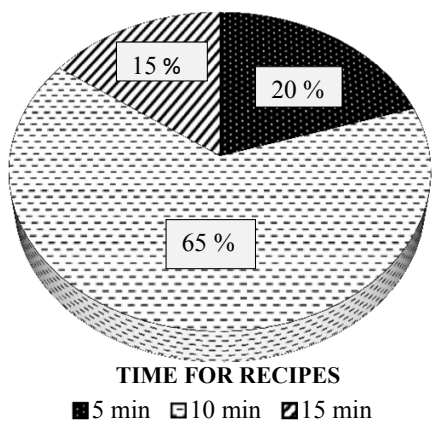

Fig. 1. Partition of respondents' answers regarding the time spent on filling a recipe in the "Available medicines" program

Table 1

Characteristics of individual indicators of the organization of work of pharmacy workers under the "Available medicines" program

\begin{tabular}{cccc}
\hline Question & $\begin{array}{c}\text { Communal Enterprise } \\
\text { "Lozova Municipal } \\
\text { Pharmacy" }\end{array}$ & $\begin{array}{c}\text { Private pharmacy of the } \\
\text { networks "Dosvid. } \\
\text { Dovira. Dopomoga." }\end{array}$ & $\begin{array}{c}\text { Private pharmacy } \\
\text { "9-1-1 Gamma-55" }\end{array}$ \\
\hline
\end{tabular}

Number of recipes accepted by 1 pharmacy worker per day from the population under

$50-60$

$100-150$

the program "Available medicines"

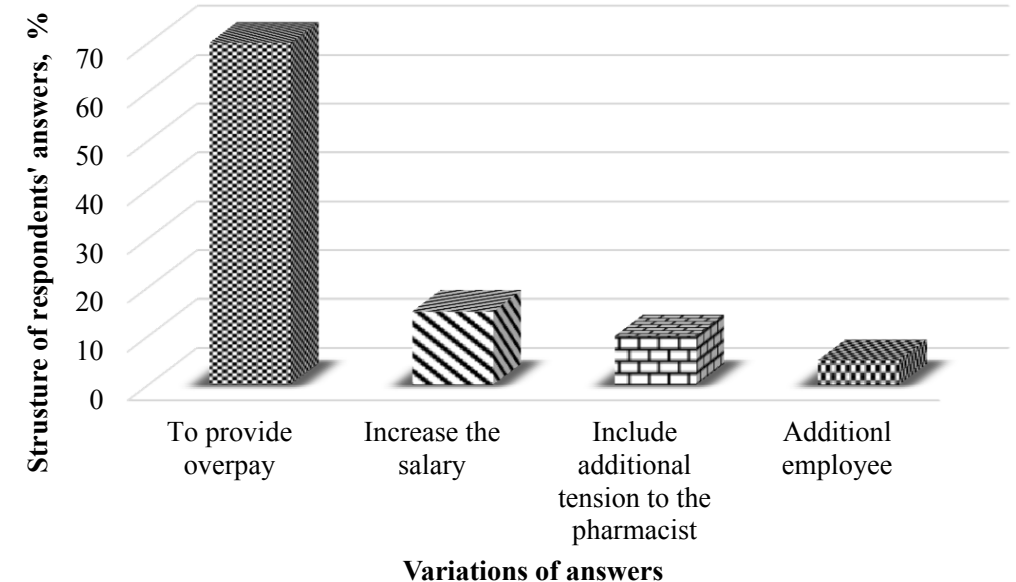

Fig. 2. Results of the survey of pharmacists on the optimization of the organization of work and its payment in connection with the work of the pharmacy in the program "Available medicines"

Thus, $70 \%$ of surveyed pharmacists consider that the best incentive and optimization of the organization of remuneration in the prevailing conditions is the remuneration for work in the drug reimbursement program, $15 \%$ of respondents said that it is worth increase salaries, $5 \%$ of employees advised to hire one more pharmacist.

\section{Discussion}

According to the survey, we have formed an indicative list of procedures performed by a pharmacist during the registration of a prescription according to the program of reimbursement of the cost of drugs has been formed: 
- checking the correctness of the design (presence of the seals of the doctor and the health care establishment, the signature of the doctor) and prescribing of the prescription;

- filling/search of data in the electronic register for reimbursement of the cost of the drug (data about the patient, doctor, prescription number, date of prescribing, nosology);

- on the reverse side of the recipe (from the top and bottom) the name of the drug, the dosage form, the dosage, the amount of the reimbursement are written. The stamp "Release" and "Free"/"Overpay", signature of the pharmacist are put.

Apparently, the volume of operations performed by pharmacists has increased significantly, and the flow of visitors to the pharmacy has not decreased, and in most cases - increased. At the same time to carry out the entire procedure of registration of the recipe pharmacist costs from $5(20 \%)$ to 15 minutes (15\%); an average of 10 minutes is spent.

Pharmacy workers, where the funds are planned in limited volumes, work under the program extremely tense in the first days of the month, sometimes releasing up to 150 recipes per day. However, the pharmacy will quickly master the funds intended for the month, therefore the greatest intensity of work under the program "Available medicines" belongs to the first decade of the month. We draw attention to the level of high intensity and intensity of pharmacists on such days, which increases several times.

In any action, the pharmacist spends his efforts, which leads to a certain result, that involves a reward [13]. Every worker needs to know that his efforts will improve the result, the better result will lead to higher rewards, and this increase will meet his expectations [14]. Motivation of labor activity can not be effective without satisfaction of material needs, orientation to the material interest of employees [15].

One of the methods of material incentives for work is overpays, which are set to compensate for additional spending of labor [16]. The increased labor intensity that takes place in pharmacies under the "Available medicines" program is the basis for the payment of overpays. Such overpays have formed the additional wages of the employees of the enterprise, as a remuneration for work exceeding the established norms and its special conditions, which are not taken into account in tariff rates and official salaries [17]. Now, overpays are irregular and periodical, in the absence of special conditions of work at the enterprise, additional payments may not be paid [18].

The feature of the work of pharmacies in the "Available medicines" program under the current conditions is the unevenness and limited funding of this project. As a result, there are widespread situations where a pharmacy runs a program up to 10 days a month, but the intensity of work of pharmacists in these days increases at a time. At the same time, in pharmacies working under the program more time or the whole month, the work of pharmacy workers is more evenly strained. Considering the above, we propose to take into account these circumstances and calculate the coefficient of the pharmacy activity' intensity for the objective accrual of the overpays to the pharmacists [19, 20].

The calculation of the amount of additional payment (overpay) for work under the conditions of the program "Available medicines" we propose to conduct for each pharmacist individually in accordance with the post by the formula:

$$
\mathrm{A}_{\mathrm{p}}=\mathrm{S} / \mathrm{W} \times \mathrm{C}_{\mathrm{i}} \times \mathrm{F} \times \mathrm{P} \%
$$

where $\mathrm{A}_{\mathrm{p}}$ - additional payment for the month, UAH; $\mathrm{S}$ - official salary, $\mathrm{UAH}$; $\mathrm{W}$ - number of working days (shifts) of the pharmacy employee per month; $\mathrm{C}_{\mathrm{i}}$ - coefficient of intensity of the pharmacy; $\mathrm{F}$ - the number of days (shifts) spent by the pharmacist by the program "Available medicines" in fact (actually); P \% - the established percentage to the calculated amount (recommended up to $12 \%$ ), determined by collective agreement, employment agreement, etc.

Accordingly, the intensity of the pharmacy Ci's work rate is calculated by the ratio of the total number of working days of the pharmacy per month to the number of days of the actual work of the pharmacy program Available medicines:

$$
\mathrm{C}_{\mathrm{i}}=\frac{\mathrm{Wd}}{\mathrm{P}}
$$


where $\mathrm{W}_{\mathrm{d}}$ - working days of the pharmacy per month; $\mathrm{P}$ - number of days of the actual work of the pharmacy under the program "Available medicines".

We had been calculated the amount of additional payments to employees at the salary established for the 12th tariff category (pharmacist) in 2019 (tariff rate 2.12), in the amount of 4073 UAH and various options for the duration of the pharmacy's program work per month $(10,15$ and 25 days), (Table 2).

Table 2

Calculation of overpays for pharmacy workers for additional work in the program "Available medicines"

\begin{tabular}{cccc}
\hline \multirow{2}{*}{ Indexes } & \multicolumn{2}{c}{ Number of days (shifts) by the program "Available medicines" in fact } \\
\cline { 2 - 4 } & $\mathbf{1 0}$ days & $\mathbf{1 5}$ days & $\mathbf{2 5}$ days \\
\hline $\begin{array}{c}\text { Coefficient of intensity, } \mathrm{C}_{\mathrm{i}} \\
\begin{array}{c}\text { Number of days of the actual work of the pharmacy } \\
\text { under the program "Available medicines" }\end{array}\end{array}$ & 3 & 2 & 1.2 \\
Volume of overpay, UAH & 5 & 7 & 12 \\
\end{tabular}

Thus, the smaller pharmacy works under the program "Available medicines" during the month, the higher is the intensity of its work these days, and on the contrary, - with a longer duration of work on a government program during the month, work is equally stressed, and therefore the intensity ratio is lower.

\section{Conclusions}

The conducted studies showed that these conclusions could be made:

1. The volume of work and its complexity in connection with the participation of pharmacies in the government program of reimbursement of the cost of drugs has increased significantly.

2. The "Available medicines" program does not provide incentives for pharmacies or pharmacy workers.

3. Increased labor intensity, which occurs in drugstores working by the "Available medicines" program, is the basis for the payment of overpays.

4. The application of the system of material incentives for pharmacists based on the proposed methodology will allow to compensate additional labor of specialists, taking into account the intensity of their work.

\section{References}

[1] Gorbunova, K. (2018). Pershyi rik prohramy «Dostupni liky»: rezultaty i perspektyvy [The first year of the «Available medicines» program: results and prospects]. Pharmacy Weekly, 14 (1185). Available at: https://www.apteka.ua/article/452916

[2] Dostupni liky: problemy ta perspektyvy [Available medications: challenges and perspectives]. Available at: http://pharmacy.kiev.ua/novyny/Dostupni_liky_problemy_ta_perspektyvy.html

[3] Halii L. V. Do pytannia normuvannia pratsi spetsialistiv farmatsii [On the issue of regulation of labor specialist pharmacy]. Available at: http://www.rusnauka.com/PNR_2006/Economics/5_galiy.doc.htm

[4] Halii, L. V. (2007). Teoretychni zasady pobudovy systemy orhanizatsii pratsi spetsialistiv farmatsii [The theoretical basis for building system of labor specialist pharmacy]. News of pharmacy, 1 (49), 59-63.

[5] Tolochko, V. M., Muzyka, T. F., Zarichkova, M. V., Dolzhnikova, O. M. (2015). Analiz zakonodavcho-normatyvnoho rehuliuvannia systemy sotsialnoho zakhystu pratsivnykiv aptechnykh zakladiv Ukrainy [Analysis of legislative and normative regulation of the system of social protection of workers of pharmacy establishments of Ukraine]. Social Pharmacy in Health Care, 1 (1), 12-17.

[6] Val, E. V. (2010). Oplata, motivy i stimuly truda na farmatsevticheskom predpriyatii [Payment, motives and labor incentives in a pharmaceutical enterprise]. Ekonomicheskiy vestnik farmatsii [Economic Journal of Pharmacy], 8, 76-82. 
[7] Grishin, A. V., Luzyanini, E. S. (2010). Analiz effektivnosti primineniya pooschreniy dlya trudovoy motivatsii spetsialistov aptechnogo predpriyatiya [Efficacy of nonfinancial incentives application for job motivation in pharmacy workers]. Bulletin of Siberian medicine, 1, 119-124.

[8] Gorbunova, K. (2013). Pytannia normuvannia robochoho chasu pratsivnykiv aptek [Questions of the standardization of working time of pharmacists]. Pharmacy Weekly, 28 (899). Available at: https:// www.apteka.ua/article/242919

[9] Prykhodko, O. (2017). Uriadova prohrama «Dostupni liky» yak element medychnoi reformy [Government program «Available medicines» as an element of medical reform]. Pharmacy Weekly, 22 (1093). Available at: https://www.apteka.ua/article/413569

[10] Pidturkin, D. (2017). Prohrama «Dostupni liky» - khodinnia po hrabliakh [The program «Available medicines» - walking on rabbles]. Available at: https://racurs.ua/ua/1639-hodinnya-po-grablyah-pidsumky-chotyroh-misyaciv-realizaciyi-programy-dostupni-liky.html

[11] Lisovskiy, P. (2015). Sistemy oplaty: kazhdomu - po trudu [Payment systems: for everyone - by work]. Pharmaceutical review, 11 (162), 22-30.

[12] Prikhodko, E. (2009). Evropeyskiy opyt aptechnogo dela [European pharmacy experience]. Pharmacy Weekly, 3 (674). Available at: https://www.apteka.ua/article/7702

[13] Kharchenko, T. M. (2010). Materialne stymuliuvannia personalu yak skladova rozvytku pidpryiemstv [Material incentives for staff as a component of enterprise development]. Bulletin of the Khmelnytsky National University, 3 (3), 129-131.

[14] Derevianko, S. I. (2015). Materialne stymuliuvannia pratsi yak osnovnyi element motyvatsii robitnykiv [Material stimulation of labor as the main element of the motivation of workers]. First Independent Scientific Herald, 3, 120-126.

[15] Shatalova, T. N., Elenvarenko, A. A. (2007). Faktor motivatsii v strukture ekonomicheskogo mekhanizma organizatsii truda [Motivation factor in the structure of the economic mechanism of labor organization]. Bulletin of OGU, 8, 77-84.

[16] Synko, N. (2013). Oplata pratsi: nadbavky i doplaty [Remuneration and supplements]. Visnyk podatkovoi sluzhby Ukrainy [Bulletin of the Tax Service of Ukraine], 47 (571), 33.

[17] Zabashtanskyi, M., Syrbu, I. (2016). Kontseptualni zasady stymuliuvannia pratsi personalu pidpryiemstva [Conceptual aspects of enterprise's personnel labor encouragement]. Problems and prospects of economy and management, 1 (5), 45-51.

[18] Semenov, H. A., Semenov, A. H., Yaroshenska, O. V. (2014). Osoblyvosti orhanizatsii oplaty pratsi na pidpryiemstvakh $\mathrm{v}$ suchasnykh umovakh [Features of the organization of labor remuneration in enterprises in modern conditions]. Bulletin of Economic Science of Ukraine, 3 (27), 100-104.

[19] Kuzovenkova, N. V. (2015). Normuvannia pratsi yak faktor pidvyshchennia konkurentospromozhnosti pidpryiemstva [Rationing labor as a factor in increasing the competitiveness of the enterprise]. Bulletin of the Kamyanets-Podilsky National University named after Ivan Ogienko, 10, 294-298.

[20] Krainii, V. O. (2014). Vdoskonalennia systemy normuvannia pratsi v suchasnykh umovakh [Improving the system of regulation of labor in modern conditions]. Global and national problems of the economy, 1, 92-96. 